\title{
Contribution to the occurrence of mosses from Orthotrichum and Nyholmiella genera in Crimean Peninsula (Ukraine)
}

Contribution to the occurrence of mosses from Orthotrichum and Nyholmiella genera in Crimean Peninsula (Ukraine). - Acta Mus. Siles. Sci. Natur., 63: 55-59, 2014.

\begin{abstract}
The paper compares recent and known literature records of mosses from genera Orthotrichum and Nyholmiella in Crimean Peninsula (Ukraine). Field survey was carried out during botanical expedition to Crimean Peninsula in southern Ukraine in 2012. Total 11 species of the genus Orthotrichum and 1 of Nyholmiella were recorded. Among the most interesting taxa, O. lyellii as new species for Crimean Peninsula and O. affine var. bohemicum as new species for Ukraine, could be considered.
\end{abstract}

Key words: Nyholmiella, Orthotrichum, Crimean Peninsula, Ukraine

\section{Introduction}

Recently published check-list of Crimean bryophytes includes 312 species (Partyka 2005). The list was arranged on the base of literature data and recent collection. Orthotrichaceae family is represented by 2 species of genus Zygodon, 13 species of genus Orthotrichum 2 species of genus Nyhollmiella and only 1species of genus Ulota. Other literature sources reported different numbers of species but taxonomical value of some of them is questionable (cf. Baczuryna \& Melniczuk 1989).

The article is a supplement including new data about the bryoflora of Crimean Peninsula.

\section{Methods}

The studied areas are located in the southern part of Ukraine (see map - Fig. 1). The survey focused to epiphytic bryophytes was carried out during botanical expedition to Crimean Peninsula in May 2012. Many different habitats were visited on altitude between $11 \mathrm{~m}$ a.s.l. on the seaside area to $1167 \mathrm{~m}$ a.s.l. in Ai Petri Mt.

Recent finding were compared with published data, mainly those from the Moss flora of Ukrainian SSR (Bachurina 1989) and Bryoflora of Crimea (Partyka 2005).

The specimens are kept in herbarium of University of Ostrava (OSTR). All samples were collected and subsequently determined by author.

\section{List of localities:}

1. $2 \mathrm{~km} \mathrm{NE}$ from the Rezervne village, greenwood in slope, S of a public road No. H11, 232 m a.s.l., GPS (WGS-84): N4430'21.6" E3341'26.0"

2. $2.5 \mathrm{~km}$ NE from the Honchame village, greenwood situated $100 \mathrm{~m} \mathrm{~N}$ of a public road No. H19, $232 \mathrm{~m}$

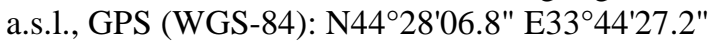

3. $\quad 1.3 \mathrm{~km}$ NE from the Foros town, along a public road "Stare Sevastopolske shosse", greenwood in slope, 1.5 NW km of a church, 455 m a.s.l., GPS (WGS-84): N44²4'27.8" E3347'22.8"

4. Nikita town, $5 \mathrm{~km}$ SEE from the Voskhod town, Nikitska Botanical Garden, $60 \mathrm{~m}$ of seaside, in Cape Martyan Reserve, 11 m a.s.l., GPS (WGS-84): N44³0'21.6" E34²14'55.5"

5. $2.1 \mathrm{~km}$ NNW from the Lavanda village, greenwood near the Angarsk Pass about $250 \mathrm{~m}$ N from camp: 846 m a.s.l., GPS (WGS-84): N44²4'09.8" E34²0'11.9"

6. $\quad 4.5 \mathrm{~km}$ NNW from the Lavanda village, $2.5 \mathrm{~km}$ NW from the Angarsk pass, upper edge of greenwood, 2.3 $\mathrm{km} \mathrm{N}$ from camp, in a forest, $1111 \mathrm{~m}$ a.s.l., GPS (WGS-84): N44²4'28.5" E34¹9'26.4"

7. $\quad 4.3 \mathrm{~km}$ NNW from the Lavanda village, $2.3 \mathrm{NW}$ from the Angarsk pass, $2.1 \mathrm{~km} \mathrm{~N}$ from camp, solitary tree in upper part of the greenwood, 1167 m a.s.l., GPS (WGS-84): N4444'34.8" E34¹9'20.6"

8. $500 \mathrm{~m}$ SWW from the Shchebetovka village, $1.8 \mathrm{~km}$ NEE of the Krasnokam'yanka village, greenwood in slope along public road, 95 m a.s.l., GPS (WGS-84): N4455'14.5" E35¹2'51.1" 


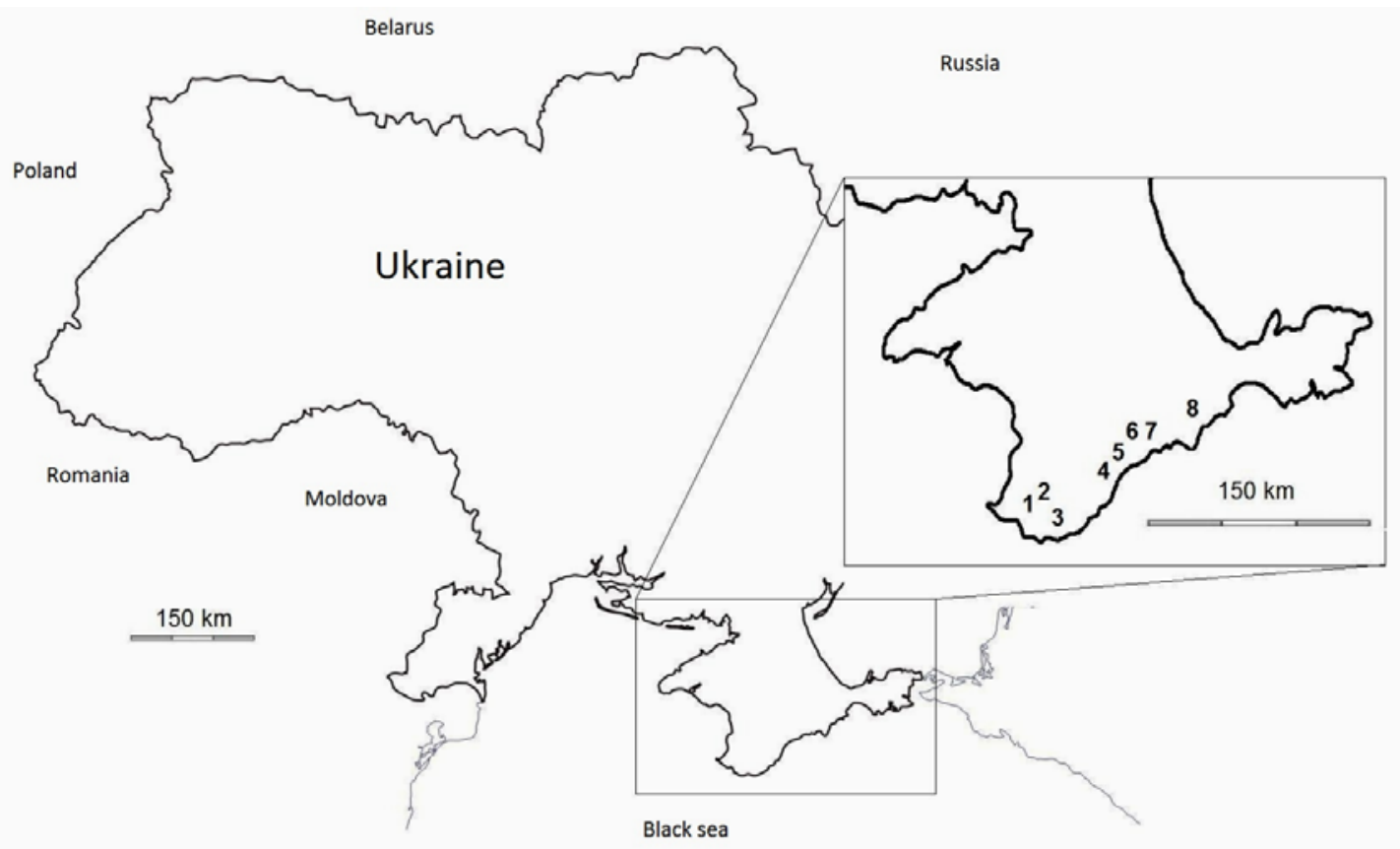

Fig. 1: Map of Crimean Peninsula (Ukraine) with marked localities.

\section{A list of recorded species}

The taxa are given in alphabetical order. Numbers of localities are written in bold. The phorophyte species on which the moss specimens were recorded is written in italic.

The nomenclature of recorded bryophytes follows Lara et al. 2009 and Plášek et al. 2011.

\section{Nyholmiella obtusifolia}

Loc.: 2 (27.V.2012, Quercus); 6 (29.V.2012, Fagus).

An occurrence of the species is known from Crimean Peninsula (Bachurina et al. 1989, Partyka 2005).

\section{Orthotrichum affine}

Loc.: 1 (27.V.2012, Acer); 1 (27.V.2012, Ulmus); 2 (27.V.2012, Fagus); 2 (27.V.2012, Quercus); 1 (27.V.2012, Quercus); 2 (27.V.2012, Quercus); 2 (27.V.2012, Quercus); 2 (27.V.2012, Fagus); 2 (27.V.2012, Fagus); 2 (27.V.2012, Cornus); 2 (27.V.2012, Ulmus); 2 (27.V.2012, Quercus); 2 (27.V.2012, Fagus); 3 (27.V.2012, Quercus); 3 (27.V.2012, Fagus); 3 (27.V.2012, Quercus); 3 (27.V.2012, Acer); 4 (28.V.2012, Quercus); 5 (29.V.2012, Crataegus); 5 (29.V.2012, Fagus); 5 (29.V.2012, Fagus); 5 (29.V.2012, Fagus); 5 (29.V.2012, Quercus); 5 (29.V.2012, Fagus); 5 (29.V.2012, Quercus); 5 (29.V.2012, Quercus); 8 (31.V.2012, Malus); 8 (1.VI.2012, Quercus).

The most common species of the genus Orthotrichum there. Rich literature data from the area are presented also in Bachurina et al. (1989) and Partyka (2005).

\section{Orthotrichum affine var. bohemicum}

Loc.: 5 (29.V.2012, Quercus).

New taxa for Crimean Peninsula and whole Ukraine found in a small population growing on bark of Quercus sp. in greenwood near Angarsk Pass. 


\section{Orthotrichum anomalum}

Loc.: 2 (27.V.2012, Fagus).

Typically growing on rocks, O. anomalum were found only once on the bark of Fagus. An occurrence of the taxa in the area is reported in Bachurina et al. 1989 and Partyka 2005.

\section{Orthotrichum diaphanum}

Loc.: 1 (27.V.2012, Quercus); 2 (27.V.2012, Acer); 2 (27.V.2012, Quercus); 2 (27.V.2012, Quercus).

Species growing in SW peak of Crimean Peninsula were found in its lower parts up to 250 $\mathrm{m}$ a.s.l. An occurrence of the taxa in the area is reported in Bachurina et al. (1989) and Partyka (2005).

\section{Orthotrichum lyellii}

Loc.: 2 (27.V.2012, Ulmus).

New taxa for Crimean Peninsula. Population without capsules was found growing sporadicly on bark of Ulmus sp. in the greenwood about $100 \mathrm{~m}$ from public road.

\section{Orthotrichum palens}

Loc.: 1 (27.V.2012, Ulmus); 1 (27.V.2012, Quercus); 2 (27.V.2012, Quercus); 2 (27.V.2012, Acer); 2 (27.V.2012, Quercus)

Species growing in SW peak of Crimean Peninsula were found in its lower parts up to 250 $\mathrm{m}$ a.s.l. (the same localities as Orthotrichum diaphanum). An occurrence of the taxa in the area is reported in Bachurina et al. (1989) and Partyka (2005).

\section{Orthotrichum pumilum}

Loc.: 1 (27.V.2012, Ulmus); 1 (27.V.2012, Quercus); 2 (27.V.2012, Cornus); 2 (27.V.2012, Quercus); 2 (27.V.2012, Quercus); 2 (27.V.2012, Quercus); 2 (27.V.2012, Quercus); 2 (27.V.2012, Quercus); 3 (27.V.2012, Fagus); 4 (28.V.2012, Quercus); 6 (29.V.2012, Quercus); 8 (1.VI.2012, Fagus).

Common species growing in rich populations especially on second locality; usually on Quercus sp. An occurrence of the taxa in the area is reported in Bachurina et al. (1989) and Partyka (2005).

\section{Orthotrichum rupestre}

Loc.: 4 (28.V.2012, Quercus).

Species found growing only once on locality close to the seaside. Although it is rather epilithic moss, in the studied area was recorded growing on a bark of oak tree. An occurrence of the taxa in the area is reported in Bachurina et al. (1989) and Partyka (2005).

\section{Orthotrichum speciosum}

Loc.: 1 (27.V.2012, Ulmus); 1 (27.V.2012, Quercus); 2 (27.V.2012, Quercus); 2 (27.V.2012, Fagus); 2 (27.V.2012, Fagus); 5 (29.V.2012, Crataegus); 5 (29.V.2012, Fagus); 5 (29.V.2012, Fagus); 8 (1.VI.2012, Quercus).

Common species growing in many localities of Crimean Peninsula. An occurrence of the taxa in the area is reported in Bachurina et al. (1989) and Partyka (2005).

\section{Orthotrichum stramineum}

Loc.: 2 (27.V.2012, Fagus); 2 (27.V.2012, Quercus); 3 (27.V.2012, Quercus); 5 (29.V.2012, Fagus); 5 (29.V.2012, Fagus); 5 (29.V.2012, Fagus); 5 (29.V.2012, Quercus); 5 (29.V.2012, Fagus); 6 (29.V.2012, Fagus);

Species growing mostly on Fagus sp. and Quercus sp. in a various localities all around the Crimean Peninsula. An occurrence of the taxa in the area is reported in Bachurina et al. (1989) and Partyka (2005). 


\section{Orthotrichum striatum}

Loc.: 1 (27.V.2012, Acer) ; 1 (27.V.2012, Ulmus); 2 (27.V.2012, Fagus); 2 (27.V.2012, Acer); 2 (27.V.2012, Fagus); 2 (27.V.2012, Cornus); 2 (27.V.2012, Ulmus); 2 (27.V.2012, Quercus); 2 (27.V.2012, Fagus); 3 (27.V.2012, Quercus); 3 (27.V.2012, Fagus); 3 (27.V.2012, Acer); 5 (29.V.2012, Fagus); 5 (29.V.2012, Fagus); 5 (29.V.2012, Fagus); 5 (29.V.2012, Quercus); 5 (29.V.2012, Fagus); 5 (29.V.2012, Fagus); 5 (29.V.2012, Quercus); 5 (29.V.2012, Quercus); 7 (29.V.2012, Fagus); 8 (1.VI.2012, Fagus).

A common species in the Crimean penisula growing mostly on bark of Fagus sp. and Quercus sp. An occurrence of the taxa in the area is reported in Bachurina et al. (1989) and Partyka (2005).

\section{Ulota crispa}

Loc.: 2 (27.V.2012, Quercus).

Only one species of genus Ulota was found growing on Quercus sp. in small population in SW part of Crimean penisula. An occurrence of the taxa in the area is reported in Bachurina et al. (1989) and Partyka (2005).

Taxa non confirmed in the field recently

\section{Nyholmiella gymnostoma}

Lit.: Bachurina et al. (1989), Partyka (2005).

\section{Orthotrichum cupulatum}

Lit.: Bachurina et al. (1989), Partyka (2005).

Orthotrichum cupulatum var. riparium

Lit.: Bachurina et al. (1989), Partyka (2005).

Orthotrichum tenellum

Lit.: Bachurina et al. (1989), Partyka (2005).

\section{Discussion}

A total of 12 species have been recently found in the studied areas: Nyholmiella obtusifolia, Orthotrichum affine, O. affine var. bohemicum, O. anomalum, O. diaphanum, $O$. lyellii, $O$. diaphanum, $O$. pumilum, $O$. rupestre, O. speciosum, $O$. stramineum and $O$. striatum. Previously reported Nyholmiella gymnostoma, Orthotrichum cupulatum, $O$. cupulatum var. riparium, and $O$. tenellum were not found in the field recently.

Among the most interesting taxa recorded in the studied area are O. lyellii and $O$. affine var. bohemicum. The first one, Orthotrichum lyellii is usually growing on deciduous trees, less often on rocks and coniferous trees. Species is known from Ukraine, but it was first found in the Crimean Peninsula, growing as one population on the bark of Ulmus sp. in the greenwood. Plants were sterile, but typical gemmae on leafs were present.

The moss Orthotrichum affine var. bohemicum, was described recently from the Czech Republic by Plášek et al. (2011). In many features Orthotrichum affine var. bohemicum is similar to the type variety, but it can be easily distinguished by its 16 endostome segments. It appears that this variety is widespread geographically. However, untill now it was reported only from the Czech Republic (Plášek et al. 2011, Plášek \& Benešová 2013, Halfar \& Plášek 2014), USA (Ellis et al. 2012a), Poland (Ellis et al. 2012b) and Sweden (Ellis et al. 2013). 
Acknowledgement: The study has been carried out in connection with the project of the Institute of Environmental Technologies, reg. no. CZ.1.05/2.1.00/03.0100 supported by the Research and Development for Innovations Operational Program, financed by Structural Funds of the European Union and the state budget of the Czech Republic and Project LO1208 of the National Feasibility Programme I of the Czech Republic.

\section{References}

Baczuryna G.F. \& Melniczuk W.M. (1989): Moss Flora of Ukraine, Part 3 [Flora Mchuv Ukrainskoj SSR vypusk 3]. Kiev: Naukova Dumka, 176 pp. (in Ukrainian)

Ellis L.T., Alegro, A., Bednarek-Ochyra H., Ochyra R., Bergamini A., Cogoni A., Erzberger P., Górski P., Gremmen N., Hespanhol H., Vieira C., Kurbatova L.E., Lebouvier M., Martinčič A., Asthana A.K., Gupta R., Nath V., Natcheva R., Ganeva A., Özdemir T., Batan N., Plášek V., Porley R.D., Randić M., Sawicki J., Schroder W., Sérgio C., Smith V.R., Sollman P., Ştefănuţ S., Stevenson C.R., Suárez G.M., Surina B., Uyar G. \& Surina Z.M. (2012a): New national and regional bryophyte records, 31. - Journal of bryology 34: 123-134.

Ellis L.T., Bednarek-Ochyra H., Ochyra R., Cykowska B., Dulin M.V., Ezer T., Kara R., Flores J.R., Suárez G.M., Garcia C., Martins A., Sérgio C., Garilleti R., Kirmaci M., Agcagil E., Kurbatova L.E., Lebouvier M., Papp B., Szurdoki E., Philippov D.A., Plášek V., Pócs T., Sabovljević M., Sawicki J., Sim-Sim M., Szűcs P., Bidló A., Váňa J., Vigalondo B., Lara F., Draper I., Virchenko V.M. \& Wolski G.J. (2012b): New national and regional bryophyte records, 33. - Journal of bryology 34: 281-291.

Ellis L.T., Bednarek-Ochyra H., Ochyra R., Benjumea M.J., Saïs L.V., Caparrós R., Lara F., Mazimpaka V., Dulin M.V., Garilleti R., Gremmen N., Grundling P.-L., Heras P., Infante M., Huttunen S., Ignatov M.S., Korvenpää T., Lebouvier M., Lewis Smith R.I., Lin S.-H., Yang J.D., Linström A., Plášek V., Rosselló J.A., Sawicki J., van Rooy J., Smith V.R. (2013): New national and regional bryophyte records, 35. - Journal of bryology 35: 129-139.

Halfar J. \& Plášek V. (2014): New records of moss Orthotrichum affine var. bohemicum Plášek \& Sawicki from Silesia (Czech Republic). - Acta Mus. Siles. Sci. Natur. 63: 25-28.

Lewinsky J. (1993): A synopsis of the genus Orthotrichum Hedw. (Musci, Orthotrichaceae). - Bryobrothera 2: $1-59$.

Partyka L.Y. (2005): Bryoflora of Crimea. [Бриофлора Крыма] Kiev: N.G. Kholodny’ Inst. Bot. NAN, 170 pp. (in Ukrainian)

Plášek V. \& Benešová H. (2013): New records of recently described moss Orthotrichum affine var. bohemicum Plášek \& Sawicki in western Bohemia (Czech Republic). - Čas. Slez. Muz. Opava (A) 62: 15154.

Plášek V., Sawicki J., Marková I. \& Wierzcholska S. (2011): Orthotrichum affine var. bohemicum (Orthotrichaceae), a new variety of epiphytic moss from the Czech Republic. - Acta Societatis Botanicorum Poloniae 80: 335-40.

Author's address: Lukáš Číhal, University of Ostrava, Chittussiho 10, 71000 Ostrava, Czech Republic, e-mail: cihallukas@email.cz 